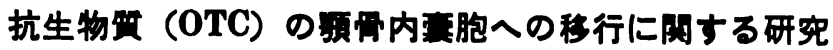

\author{
村田雄一
}

\section{A clinical study on transfer of oxytetracycline into the cyst of the jaw}

Yuichi Murata

\section{楮}

\section{言}

口腔外科領域には，しばしば蕉胞の形成がみられるが， それらの発生頻度は，Bhaskar(1966) 1) 伊藤ら(1969)2)， および齐藤ら (1973) 3) の研究によれば，颉骨およびロ

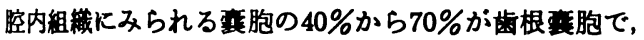

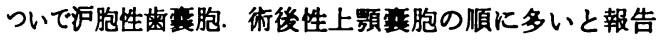

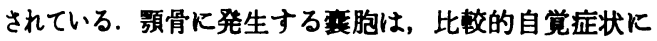
とぱしく，大きく発育して腫脹に気付いたり，萁胞の感 染によって発見されることが多い.また解剖学的にも組 絊の深部に位置していることが多いため、ひとたび感染 した場合には，その周囲組䄳に広範な炎症を惹起する。

この場合まず抗生物質を投与して，その症状の継解をは かろ. また摘出などの外科的療法を行ら場合にも，局所 の感染予防の目的で抗生物質の投与を行らことわ少くな い. しかし抗生物質の抗菌作用は生体内でしかる病巣部 において直接病原菌に作用するすのであるから，その投 与方法, 投与量はるちろん, 血中湌度および組織臓器内 缶度の変化を知ることは重要な問題である.したがって, 抗生物質の体内分布に関する研究は盛んに行われてきた. すなわらテトラサイクリンに関しては，大久保 (1954)4). 国部 $(1957)^{5)}$ ，鳥居 $(1960)^{6)}$ ，嶋田 $(1972)^{7)}$ ら多くの 研究報告がみられる。な腔外科に関しては, 成川 $(1958)^{8)}$ ，内藤 $(1963)^{9)}$ などの口腔組織内浱度の報告が, 页組維については，服部 $(1965)^{10)}$, 玉井 $(1971)^{11}$ らの 䬣告かみられる. そして数種の抗生物質の比較に関する るのとしては，大久保 $(1955)^{12)}$, 藤木 (1956) ${ }^{13)}$, 買手

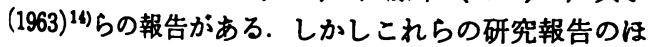
とんどは動物を用いて，その血中濃度および組織臟器内 度を測定したすのである. 一方臨床に用いた場合，人 体のしかる病巣部における浱度を知ることはきわめて重

大㤆齿科大学口堅外科学教室第一講座

(主任：高須 淳教授)

First Department of Oral Surgery, Osaka Dental University (Chief : Prof. Jun Takasu)

受付 昭和50年 6 月 2 日
要なことであるが，人体の口腔組織内洪度に関する研究 は, 岩沢 (1969) ${ }^{16)}$, 五十風 (1958) ${ }^{16)} ら か ゙$ 上影洞粘膜お よびロ蓋扁桃について，報告しているにすぎない，全身 投与された抗生物質か，言胞壁や樭胞内容液に到達し， しかも抗菌効果を示す灌度に達し，どの程度の時間その 浱度を維持できるすのなのか全く不明である．とくに烡 胞内容液中の薬物㳻度に関する研究は見当らない，そこ で著者は，臨床的に各種の烡胞と診断された患者に，オ キシテトラサイクリン（以下 OTC と略す）を静脈内注

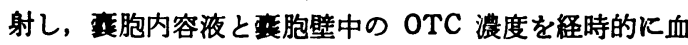
中浱度と比較測定し， OTC の病巣内移行について㭘索 した.

\section{研究対象およひ使用菜物}

\section{1. 研究对象}

研究対象は, 昭和 46 年 3 月から約 1 年 6 カ月間に大阪 齿科大学付属病院を訪れた患者の中から，臨床所見およ びX線所見で䅈根毫胞, 口蓋烡胞, 術後性上頻衰胞, 汇胞性歯琵胞，胞性エナメル上皮腫と診断されたるの の中から, 当該部位に急性の炎症症状のないもので, 問 診によって 1 週間以内に抗生物質の投与を受けていない ことを確認し，さらに採取した内容液に血液の混入の認 められたものや, 内容液の粘稠度が大きいるの, および 術前に採取した血液か：Bacillus subtilis PCI 219 株に

表 1 衰胞の種類

\begin{tabular}{|c|c|c|c|}
\hline & $q$ & $\hat{\delta}$ & \\
\hline 县 & 14 & 15 & 29 \\
\hline 汇 胞 性 歯 亯 胞 & 2 & 1 & 3 \\
\hline 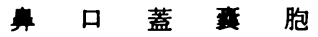 & 2 & 2 & 4 \\
\hline 球 状 上颚 胞 & & 1 & 1 \\
\hline 術後性上額 毫胞 & 1 & 2 & 3 \\
\hline エナメル上皮腫（真胞性） & 3 & 2 & 5 \\
\hline 計 & 22 & 23 & 45 \\
\hline
\end{tabular}


<smiles>CN(C)C1C(O)=C(C(N)=O)C(=O)C2(O)C(O)=C3C(=O)c4c(O)cccc4C(C)(O)C3C(O)C12</smiles>

Oxytetracycline

is $i$ 式: $\mathrm{C}_{2} \mathrm{H}_{14} \mathrm{O}_{0} \mathrm{~N}_{2}$

st $f$ : $: 460.4$

䖵 $185 \%$

图1 OTC の情造式

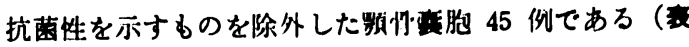
1 ).

\section{2. 使用落物}

Terramycin®觧注液（台糖ファイザー社) $3 \mathrm{ml}$ 中オ キシテトラサイクリン塩基 $250 \mathrm{mg}$ 含有（pH 8〜9）を 用いた（因1）。

\section{研究の方法}

\section{1. 莱物の投与法}

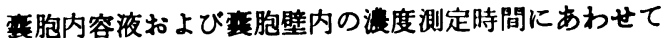
粪胞摘出手術前に Terramycin@ $250 \mathrm{mg} / 3 \mathrm{~m} l$ を $10 \mathrm{ml}$ の注射用蒸留水で稀积し, one shot 静注した.

\section{2. 血液の採取法}

OTC 静注前に患者の时正中静脈 (OTC 觧注に用いる 対側の同静脈) より 21 gage の注射針を用いて血夜を採 取し，これを対照とし，OTC 投与 5 分後，胞内容液 の採取時，および寒胞壁の摘出時にそれぞれ血液を採取 した. 採取した血液を $\mathrm{pH} 6.8 ， 0.1 \mathrm{M}$ 爟酸緅衙夜で2 倍にうすめ，ただちに遠心分離 $(3,000$ r. p. m. , $10 \mathrm{~min})$ し，その上清を被検液とした。

\section{3. 震胞内容液の採取法}

OTC 静注前に 21 gage の注射針を用いて, 丧胞内容 液を採取しこれを対照とした．また静注後，おのおの萻 胞内容液は10分〜120分にわたり，原則として 1 症例 1 回， 同様の方法で採取した．採取した内容液はただちに $\mathrm{pH}$ $6.8 ， 0.1 \mathrm{M}$ 燐酸綬衝夜で $2 \sim 4$ 倍に稀积後，上く混和 し被検液とした。

\section{4. 䨤胞壁の採取法}

OTC 静注後，通常の手術術式により烡胞壁に損伤を 与えないように，震胞摘出を行った．赛胞壁採取時間は 手術所要時間によって，左右されたが40分より 180 分ま でとした. 摘出後,暿胞壁の一部は病理組織学的検索のた め, $10 \%$ ホルマリン固定を行い, 通法による H-E 染色を ほと゚こし，娭鏡に用いた．摘出した榐胞壁は付着してい る血液と水分をよく濾紙で拭きとり，科量し，そのおの おのに $\mathrm{pH} 6.8,0.1 \mathrm{M}$ 燐酸縟衙夜を $2 \sim 4$ 倍重量加之 てホモゲナイズし，それを遠心分離 (3,000 r. p. m., 10

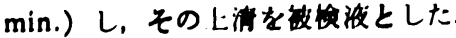

\section{OTC 湆度测定法}

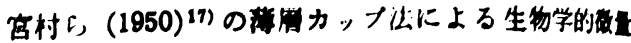
记置泣を用いた。

1) 使用陠: Bacillus subtilis PCI 219 (大限大学 微生物病研究所上り分侏）火BHI 料面培地（采研裂）

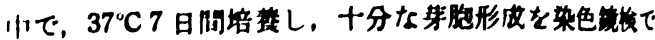

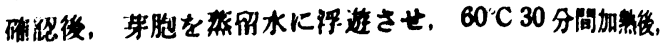

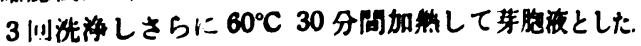

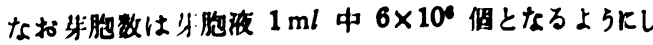
た.

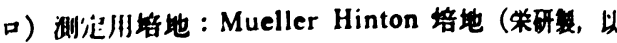
下MH培地と略す）を用いたたその组成は，以下のと

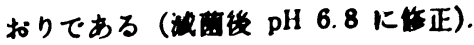

$\begin{array}{lr}\text { derivation of beef } & 300 \mathrm{gm} \\ \text { casamino acids } & 17.5 \mathrm{gm} \\ \text { starch } & 1.5 \mathrm{gm} \\ \text { agar } & 17 \mathrm{gm} \\ \text { Aq dest } & 1,000 \mathrm{~m} l\end{array}$

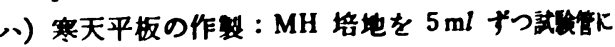

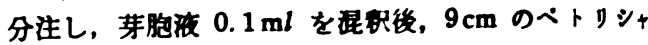
ーレに流し込み平板を作った，平板上にカっフ（屒さ $10 \mathrm{~mm}$, 外径 $8.0 \pm 0.1 \mathrm{~mm}$, 内经 $6.0 \pm 0.1 \mathrm{~mm}$, 不

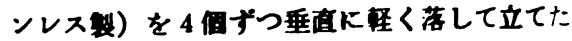

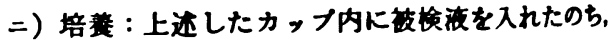
平板 $(シ+ー レ) ~ を 55^{\circ}$ C 15 時間解㢄し，寒天内に十分出

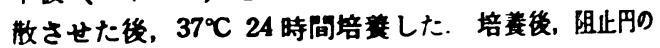
直径を $0.1 \mathrm{~mm}$ の単位まで計的した。

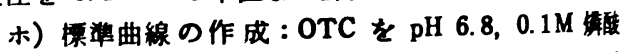
很行花に容かして $100 \mathrm{mcg} / \mathrm{ml}$ から $0.19 \mathrm{mcg} / \mathrm{ml}$ まて

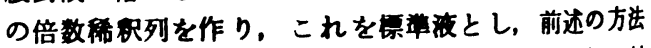
で阻止円の直经を定し，OTC $(\mathrm{mcg} / \mathrm{ml}$ ) の対

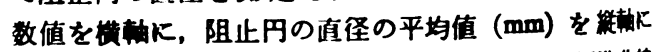

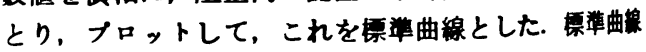

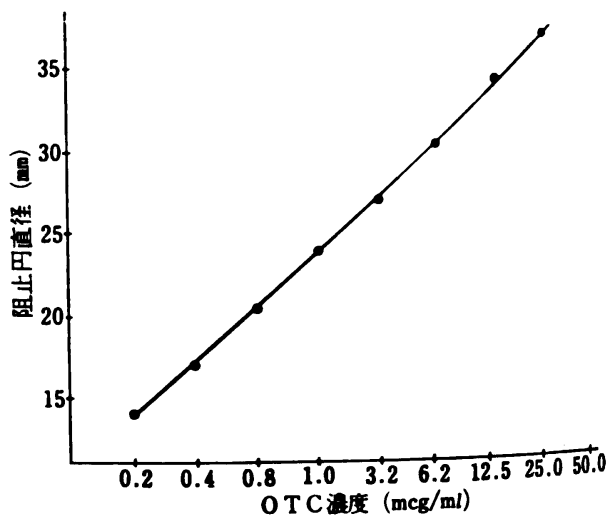

因 2 OTC の標準曲線 


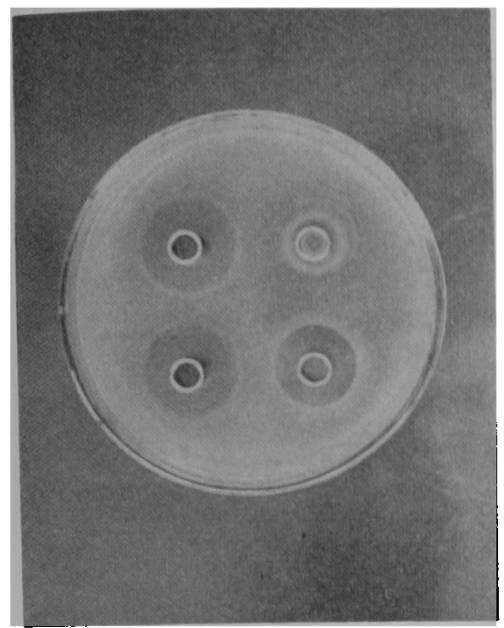

写真 1 被㭘液により現われた阻止円

は $0.19 \mathrm{mcg} / \mathrm{ml}$ から $50 \mathrm{mcg} / \mathrm{ml}$ にかけてほぼ直線と なった（図2）。

へ）被検液の湢度測定：前述の方法で採取した血液， 表胞内容收，および垔胞壁の被検液を対角線上の 2 個の カップスれ，残りのカップには既知濃度の OTC 稀釈 液を入れて培養し，おのおのの阻止円の直哇を 3 回宛測 定し，その平均値を求めた（写真 1 ）.

\section{研 究結 果}

\section{1. 毫胞内容液の抗菌性}

研究対象にした45症例の萑胞内容液の B. subtilis PCI 219 株に対する抗菌性を，静注前に調べたところ，すべ てが軽度の抗菌性を示し，それを OTC 濃度に換算した ところ，最低 $0.10 \mathrm{mcg} / \mathrm{ml}$ から最高 $0.53 \mathrm{mcg} / \mathrm{ml}$ の OTC 鋠度に相当した。

\section{2 血中浱度}

研究対象にした45症例は，静注 5 分後，趸胞内容液採 取時および践胞摘出時にそれぞれ血中濃度を測定したが， 血中漊度は静注 5 分後で最高濃度に達し，平均 12.40 $\mathrm{mcg} / \mathrm{ml}$ を示し, 30 分後では平均 $5.10 \mathrm{mcg} / \mathrm{ml}, 60$ 分 後では平均 $3.65 \mathrm{mcg} / \mathrm{ml} .120$ 分後では平均 $1.48 \mathrm{mcg} /$ nlであった（図 3).

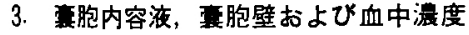

\section{A 崡根亨胞}

a. 内容液中の OTC 濃度 (図 4): OTC 静注 10 分 溇に採取した内容液は 8 例で，その濃度は（表 2）に示 †ように，最低 $0.30 \mathrm{mcg} / \mathrm{ml}$, 最高 $0.50 \mathrm{mcg} / \mathrm{ml}$ で， その時の血中濃度は最低 $8.25 \mathrm{mcg} / \mathrm{ml}$, 最高 $9.70 \mathrm{mcg} /$ 四しであった，15分後に採取したるのは 7 例で，その濃 隻は（表3）に示すように，最低 $0.40 \mathrm{mcg} / \mathrm{ml}$ ，最高 ). $68 \mathrm{mcg} / \mathrm{ml}$ で，その時の血中濃度は，最低 $5.15 \mathrm{mcg} /$ $\mathrm{ml}$ 最高 $7.35 \mathrm{mcg} / \mathrm{ml}$ であった. 30 分後に採取したも

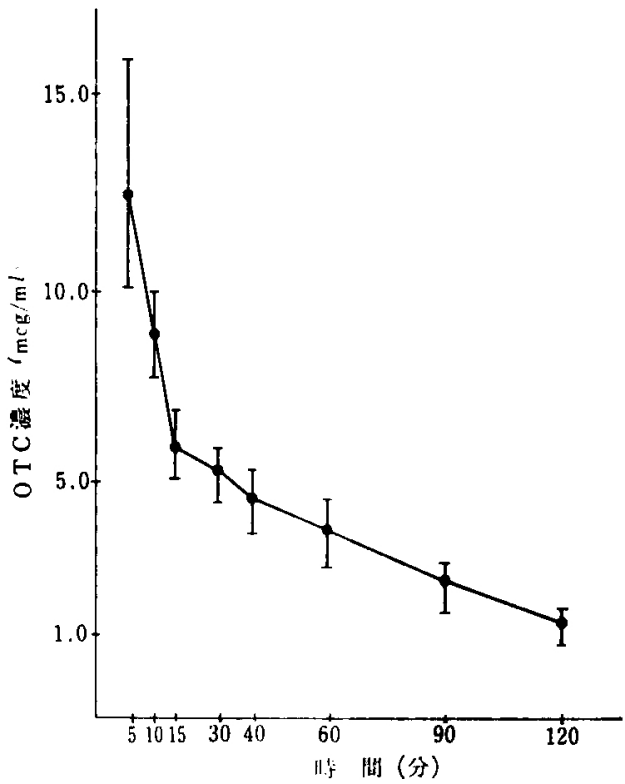

图 3 血液中の OTC 洪度

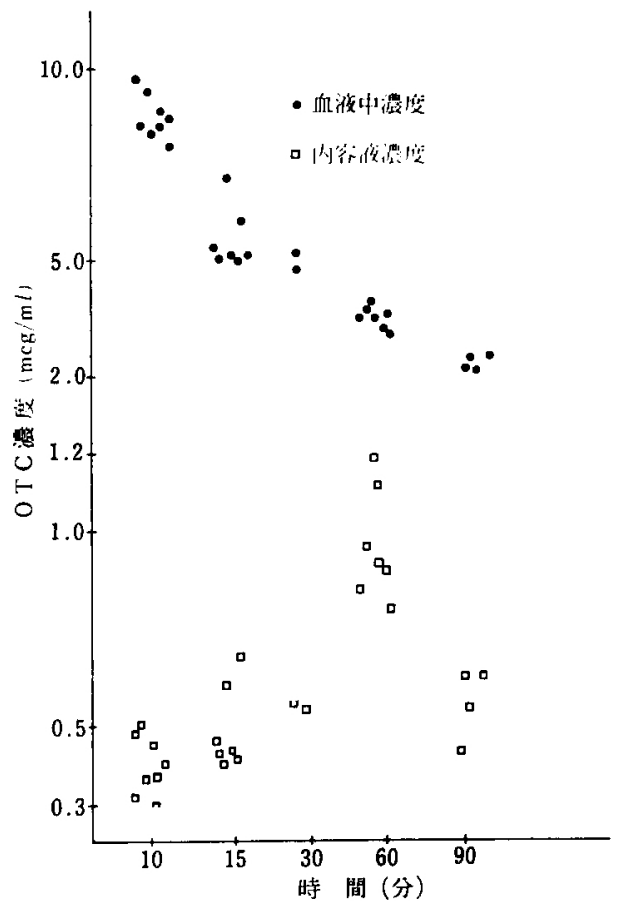

図 4 霆枹内容液の OTC 濃度 



(镥注後10分) $(\mathrm{mcg} / \mathrm{ml})$

\begin{tabular}{|c|c|c|c|}
\hline 症例潘号 & 解注的の抗薄力* & 内容波紧展 & 血浓中涉度 \\
\hline 1 & 0.41 & 0.48 & 9.70 \\
\hline 2 & 0.18 & 0.33 & 8. 55 \\
\hline 6 & 0.44 & 0.50 & 9. 40 \\
\hline 11 & 0.20 & 0.37 & 8. 45 \\
\hline 15 & 0.23 & 0.45 & 9.00 \\
\hline 22 & 0.12 & 0.30 & 8. 55 \\
\hline 24 & 0.19 & 0.38 & 8. 80 \\
\hline 28 & 0.40 & 0.40 & 8. 25 \\
\hline
\end{tabular}

* OTC, 換算値

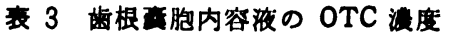
(静注後15分) $(\mathrm{mcg} / \mathrm{ml})$

\begin{tabular}{|c|c|c|c|}
\hline 症例番号 & 静注前の抗菌力* & 内容液浀度 & 血渡中淟度 \\
\hline 3 & 0.24 & 0.46 & 5. 45 \\
\hline 9 & 0.26 & 0.42 & 5. 20 \\
\hline 10 & 0.28 & 0.40 & 5. 25 \\
\hline 14 & 0.52 & 0.60 & 7. 35 \\
\hline 18 & 0.26 & 0.44 & 5. 20 \\
\hline 21 & 0.28 & 0.41 & 5. 15 \\
\hline 25 & 0.51 & 0.68 & 6. 20 \\
\hline
\end{tabular}

* OTC, 換算値

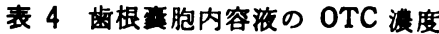
(静注後30分) $(\mathrm{mcg} / \mathrm{ml})$

\begin{tabular}{c|c|c|c}
\hline 症例番号 & 觧注前の抗菌力* & 内容液浱度 & 血液中源度 \\
\hline 4 & 0.36 & 0.55 & 5.30 \\
12 & 0.36 & 0.50 & 4.85 \\
\hline
\end{tabular}

* OTC, 換算值

表 5 歯根宾胞内容液の OTC 港度 (静注後60分) $(\mathrm{mcg} / \mathrm{ml})$

\begin{tabular}{c|c|c|c}
\hline 症例番号 & 静注前の抗菌力* & 内容液浱度 & 血液中港度 \\
\hline 5 & 0.32 & 0.85 & 3.85 \\
16 & 0.35 & 0.96 & 4.10 \\
17 & 0.35 & 1.20 & 4.25 \\
19 & 0.37 & 1.12 & 3.80 \\
20 & 0.31 & 0.92 & 3.65 \\
26 & 0.40 & 0.90 & 3.45 \\
27 & 0.37 & 0.80 & 3.40 \\
\hline
\end{tabular}

* OTC, 換算値

のは 2 例で，その湿度は（表 4）に示すよ5に，0.55, $0.50 \mathrm{mcg} / \mathrm{ml}$ で, その時の血中瀑度は $5.30,4.85 \mathrm{mcg} /$ $\mathrm{m} l$ であった. 60分後に採取したものは 7 例で，その濃 度は（表 5 )に示すように, 最低 $0.80 \mathrm{mcg} / \mathrm{ml}$, 最高1. 20

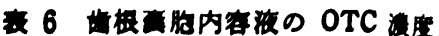
(髚注後90分) $(\mathrm{mcg} / \mathrm{ml})$

\begin{tabular}{|c|c|c|c|}
\hline 定的的等 & 注的の好的力* & 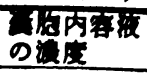 & 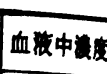 \\
\hline 7 & 0.33 & 0.45 & 2.45 \\
\hline 8 & 0.42 & 0.65 & 2.60 \\
\hline 12 & 0.37 & 0.56 & 2.40 \\
\hline 23 & 0.42 & 0.65 & 2.75 \\
\hline
\end{tabular}

\section{- OTC, 模算任}

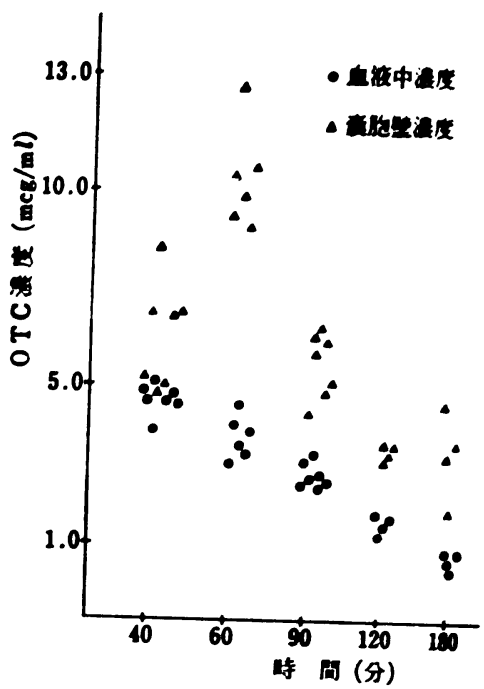

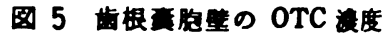

表 7 齿根算胞壁の OTC 漫度

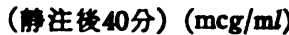

\begin{tabular}{|c|c|c|}
\hline 症例番号 & 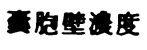 & 血液中洨度 \\
\hline 1 & 6.85 & 4.80 \\
\hline 2 & 5. 15 & 4.60 \\
\hline 6 & 8.50 & 5. 15 \\
\hline 11 & 4.65 & 3. 85 \\
\hline 15 & 5.00 & 4.65 \\
\hline 22 & 6.75 & 4. 70 \\
\hline 24 & 6.80 & 4. 50 \\
\hline
\end{tabular}

$\mathrm{mcg} / \mathrm{ml}$ で，その時の血中淡度は最低 $3.40 \mathrm{mcg} / \mathrm{ml}$ ， 很高 $4.25 \mathrm{mcg} / \mathrm{ml}$ であった. 90 分後に採取したるのは

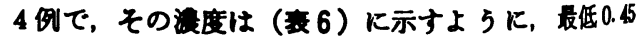

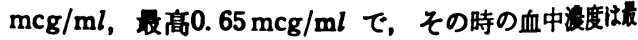
低 $2.40 \mathrm{mcg} / \mathrm{ml}$, 最高 $2.75 \mathrm{mcg} / \mathrm{ml}$ であった。

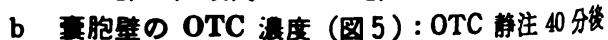

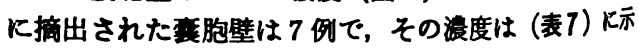
すように, 最低 $4.65 \mathrm{mcg} / \mathrm{ml}$, 最高 $8.50 \mathrm{mcg} / \mathrm{ml}$ て, その時の血中瀑度は最低 $3.85 \mathrm{mcg} / \mathrm{ml}$, 最高 $5.15 \mathrm{mcg} /$ 
表 8 歯根露胞壁の OTC 濃度

\begin{tabular}{c|c|c}
\multicolumn{3}{c}{ (静注後60分) $(\mathrm{mcg} / \mathrm{m} l)$} \\
\hline 症例番号 & 露胞壁濃度 & 血液中濃度 \\
\hline 3 & 9.35 & 3.00 \\
9 & 10.40 & 4.00 \\
10 & 12.55 & 4.45 \\
14 & 9.80 & 3.40 \\
18 & 9.00 & 3.25 \\
21 & 10.45 & 3.80 \\
\hline
\end{tabular}

表 9 歯根露胞壁の OTC 濃度 (静注後90分) $(\mathrm{mcg} / \mathrm{ml})$

\begin{tabular}{c|c|c}
\hline 症例番号 & 囊胞壁濃度 & 血液中濃度 \\
\hline 13 & 4.25 & 2.40 \\
16 & 6.35 & 3.10 \\
17 & 5.80 & 2.65 \\
19 & 6.45 & 3.25 \\
20 & 6.15 & 2.70 \\
25 & 4.80 & 2.45 \\
26 & 5.10 & 2.50 \\
\hline
\end{tabular}

表 10 歯根囊胞壁の OTC 濃度（静注後 120 分) $(\mathrm{mcg} / \mathrm{ml})$

\begin{tabular}{c|c|c}
\hline 症例番号 & 襄胞壁濃度 & 血液中濃度 \\
\hline 7 & 3.45 & 1.75 \\
8 & 3.00 & 1.20 \\
12 & 3.30 & 1.45 \\
27 & 3.45 & 1.70 \\
\hline
\end{tabular}

表 11 歯根囊胞壁の OTC 濃度（静注後 180 分) $(\mathrm{mcg} / \mathrm{ml})$

\begin{tabular}{c|c|c}
\hline 症例番号 & 囊胞壁濃度 & 血液中濃度 \\
\hline 4 & 4.65 & 0.90 \\
5 & 3.30 & 0.65 \\
23 & 1.95 & 0.45 \\
28 & 3.60 & 0.70 \\
\hline
\end{tabular}

$\mathrm{m} l$.であった. 60 分後に摘出されたものは 6 例で，その 濃度は（表 8 に) 示すように, 最低 $9.00 \mathrm{mcg} / \mathrm{ml}$, 最高 $12.55 \mathrm{mcg} / \mathrm{ml}$ で, その時の血中濃度は最低 $3.00 \mathrm{mcg} /$ $\mathrm{m} l$, 最高 $4.45 \mathrm{mcg} / \mathrm{ml}$ であった. 90 分後に摘出された あのは 7 例で, その濃度は（表 9) と示すように, 最低 $4.25 \mathrm{mcg} / \mathrm{ml}$, 最高 $6.45 \mathrm{mcg} / \mathrm{ml}$ で, その時の血中濃 度は最低 $2.40 \mathrm{mcg} / \mathrm{ml}$, 最高 $3.25 \mathrm{mcg} / \mathrm{ml}$ であった. 120 分後に摘出されたものは 4 例で, その濃度は(表10) に示すように, 最低 $3.00 \mathrm{mcg} / \mathrm{m} l$, 最高 $3.45 \mathrm{mcg} / \mathrm{ml}$ で, その時の血中濃度は最低 $1.20 \mathrm{mcg} / \mathrm{m} l$, 最高 1.75 $\mathrm{mcg} / \mathrm{ml}$ であった.

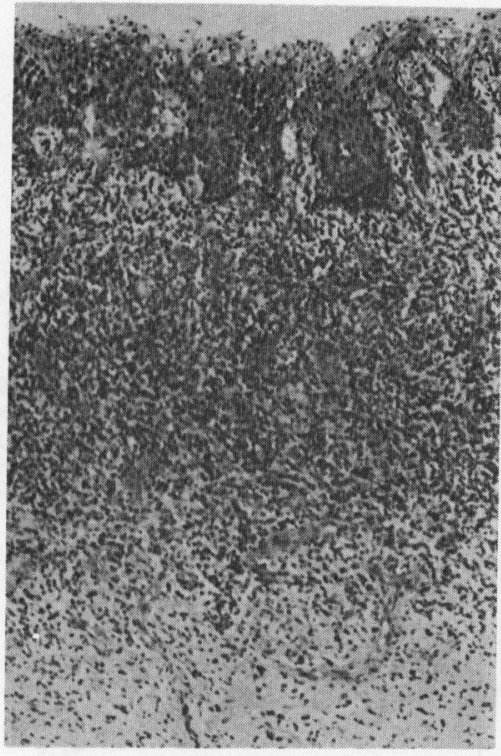

写真 2 歯根囊胞壁 (H-E 染色) 炎症性細胞浸潤が強く, 肉芽組織層に上皮索が進 入している.

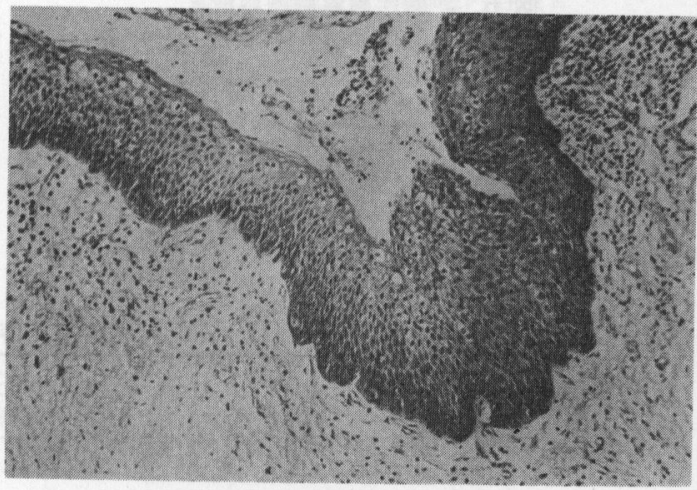

写真 3 歯根囊胞壁 (H-E 染色) 重層扁平上皮と軽度の炎 症性細胞浸潤を持った線 維性結合組織よりなる。

180 分後に摘出されたものは 4 例で，その濃度は（表 11)に示すように, 最低 $1.95 \mathrm{mcg} / \mathrm{ml}$, 最高 $4.65 \mathrm{mcg} / \mathrm{ml}$ で, その時の血中濃度は最低 $0.45 \mathrm{mcg} / \mathrm{ml}$, 最高 0.90 $\mathrm{mcg} / \mathrm{ml}$ であった.

c 囊胞壁の組織像 : 摘出した囊胞は, 直径約 $15 \mathrm{~mm}$ から $20 \mathrm{~mm}$ までのほぼ球形の袋状物で, 虽胞壁の内面 は重層扁平上皮よりなり，それに接して炎症性細胞浸潤 の強い肉芽組織の層が見られたもの（写真 2) や，比較 的炎症性細胞浸潤の軽度な肉芽組織の層よりなっている ものが見られた（写真 3 ).

B 沪胞性歯囊胞 (図 6) 


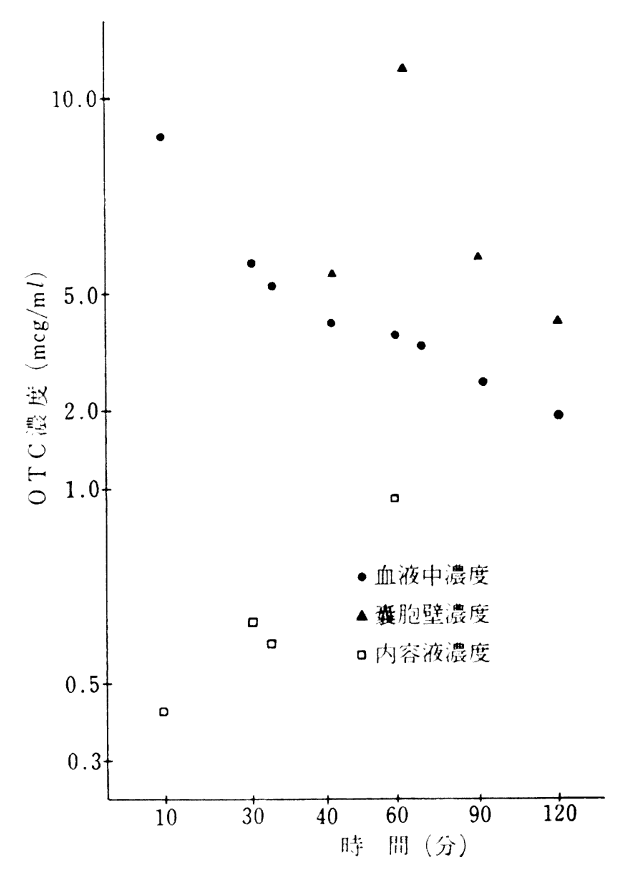

可 6 沪胞性歯颠胞内容液と 䙲胞壁の OTC 濃度

a 内容液中の OTC 濃度：OTC 静注後に採取した 内容液は 4 例で, その濃度は（表12）に示すように, 静 注10分後では $0.43 \mathrm{mcg} / \mathrm{ml}, 30$ 分後では $0.60,0.65 \mathrm{mcg} /$ $\mathrm{ml}$ そして60分後では $0.98 \mathrm{mcg} / \mathrm{ml}$ で，その時の血中 濃度は $9.10 \mathrm{mcg} / \mathrm{ml}, \quad 5.85 \mathrm{mcg} / \mathrm{ml}, \quad 5.20 \mathrm{mcg} / \mathrm{ml}$,
$3.75 \mathrm{mcg} / \mathrm{ml}$ であった.

b 霆胞壁の OTC 濃度 : OTC 静注後に摘出された 整胞壁は 4 例で, その濃度は（表13）に示すように, 静 注 40 分後では $5.45 \mathrm{mcg} / \mathrm{ml}, 60$ 分後では $10.80 \mathrm{mcg} / \mathrm{ml}$ 90 分後では $6.00 \mathrm{mcg} / \mathrm{ml}$ そして120分後では $4.30 \mathrm{mcg} /$ $\mathrm{ml}$ で，その時の血中濃度は $4.25 \mathrm{mcg} / \mathrm{ml}, 3.60 \mathrm{mcg} /$ $\mathrm{ml}, 2.75 \mathrm{mcg} / \mathrm{ml}, 1.80 \mathrm{mcg} / \mathrm{ml}$ であった.

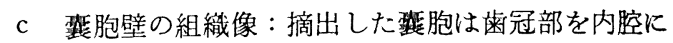
含み, 直径が $25 \mathrm{~mm}$ から $30 \mathrm{~mm}$ の卵円形で, 薄い栾 胞壁であった．内層は比較的薄い重層扁平上皮よりなり， 基底部はやや平坦で，これをとりまく線維性結合組織層 には炎症性細胞浸潤が強く見られたものはなかった（写 真 4 ).

\section{C 術後性上顎毫胞 (図 7)}

a 内容液中の OTC 濃度 : OTC 静注後に採取した 内容液は 3 例で, その濃度は（表14）に示すように, 静 注10分後では $0.21 \mathrm{mcg} / \mathrm{ml}, 30$ 分後では $0.42 \mathrm{mcg} / \mathrm{ml}$ そして 60 分後では $0.68 \mathrm{mcg} / \mathrm{ml}$ で，その時の血中濃度 は, $8.55 \mathrm{mcg} / \mathrm{ml}, 4.85 \mathrm{mcg} / \mathrm{ml}, 3.45 \mathrm{mcg} / \mathrm{ml}$ であっ た.

b : 褧胞壁の OTC 濃度 : OTC 静注後に摘出された 整胞壁は 3 例で，その濃度は（表15）に示すよ5に，杪 注 40 分後では $4.65 \mathrm{mcg} / \mathrm{ml}, 90$ 分後では $5.60 \mathrm{mcg} / \mathrm{ml}$ そして120分後では $3.55 \mathrm{mcg} / \mathrm{ml}$ で, その時の血中濃度 は $4.40 \mathrm{mcg} / \mathrm{ml}, 2.20 \mathrm{mcg} / \mathrm{ml}, 1.55 \mathrm{mcg} / \mathrm{ml}$ であった.

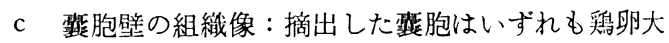

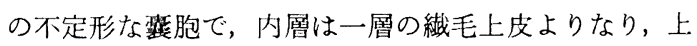
皮層下は嗳粗な線維性結合組織層で軽度の円形細胞浸潤 を伴っていた，さらにその外層部には膠原繊維に富んた

表 12 汇胞性歯胞内容液の OTC 濃度 $(\mathrm{mcg} / \mathrm{ml})$

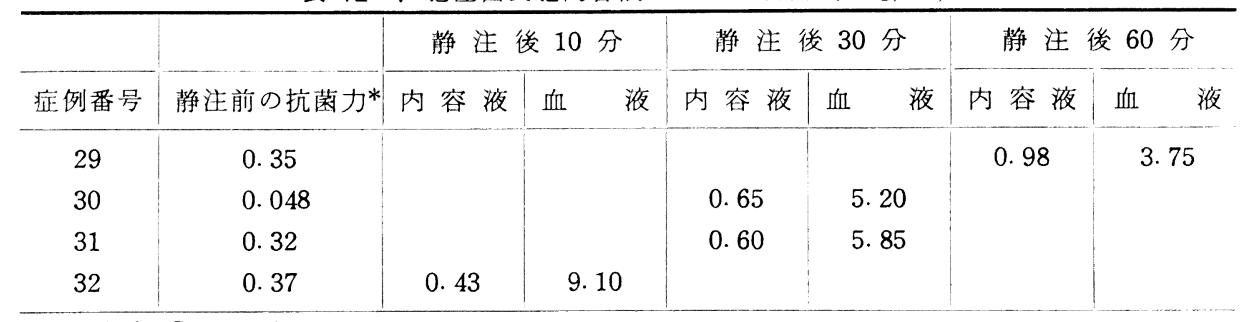

* OTC, 換算値



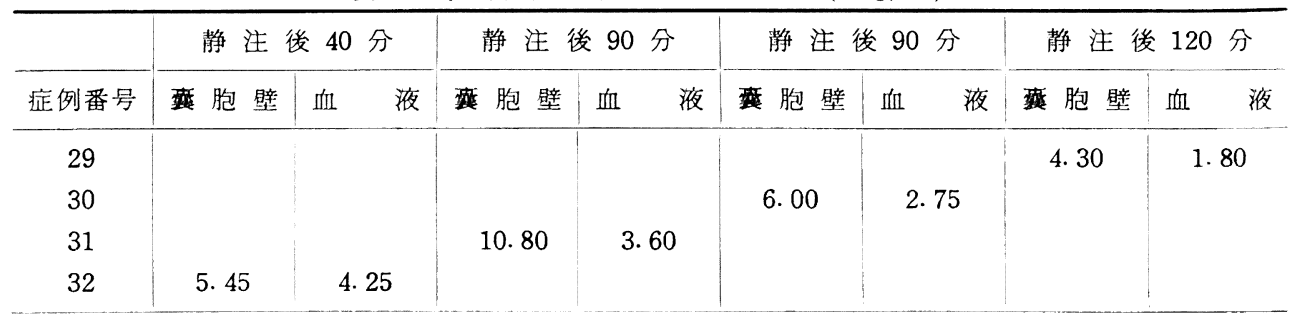




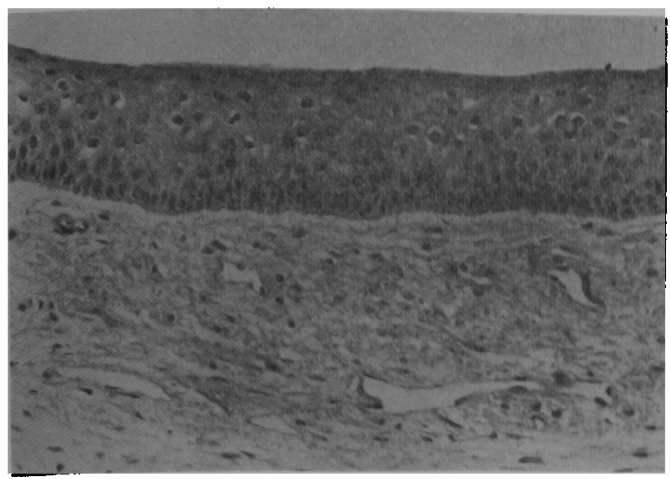

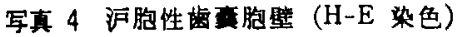
錯角化と平坦な境界を持った 重層扁平上皮層と線䊒性結合 組的屡がみられる。

結合組鐵層がみられた（写真 5 ).

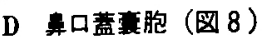

a 内容液中の OTC 濃度：OTC 静注後に採取した 内容液は 4 例で，その浱度は（表16）に示すように，瀞 注10分後では $0.48 \mathrm{mcg} / \mathrm{ml}, 30$ 分後では $0.68 \mathrm{mcg} / \mathrm{ml}$ 60 分後では $0.85 \mathrm{mcg} / \mathrm{ml}$ そして90 分後では $0.58 \mathrm{mcg} /$ $\mathrm{ml}$ て，その時の血中濃度は $9.60 \mathrm{mcg} / \mathrm{ml}, 5.10 \mathrm{mcg} /$ $\mathrm{ml}, 3.55 \mathrm{mcg} / \mathrm{ml}, 2.65 \mathrm{mcg} / \mathrm{ml}$ であった.

b 要胞壁の OTC 濃度：OTC 静注後に摘出された 㟟胞壁は 4 例で，その濃度は（表17）に示すよ5に，静 注 40 分後では $5.85 \mathrm{mcg} / \mathrm{ml}, 60$ 分後では $9.30 \mathrm{mcg} / \mathrm{ml}$, 90 分後では $6.30 \mathrm{mcg} / \mathrm{ml}$ そして120分後では $3.65 \mathrm{mcg} /$ $\mathrm{ml}$ て，その時の血中濃度は $4.55 \mathrm{mcg} / \mathrm{ml}, 3.40 \mathrm{mcg} /$ $\mathrm{ml}, 2.60 \mathrm{mcg} / \mathrm{ml}, 1.60 \mathrm{mcg} / \mathrm{ml}$ であった.

c 毫胞壁の組穖像：摘出した萑胞は直径が約 $15 \mathrm{~mm}$

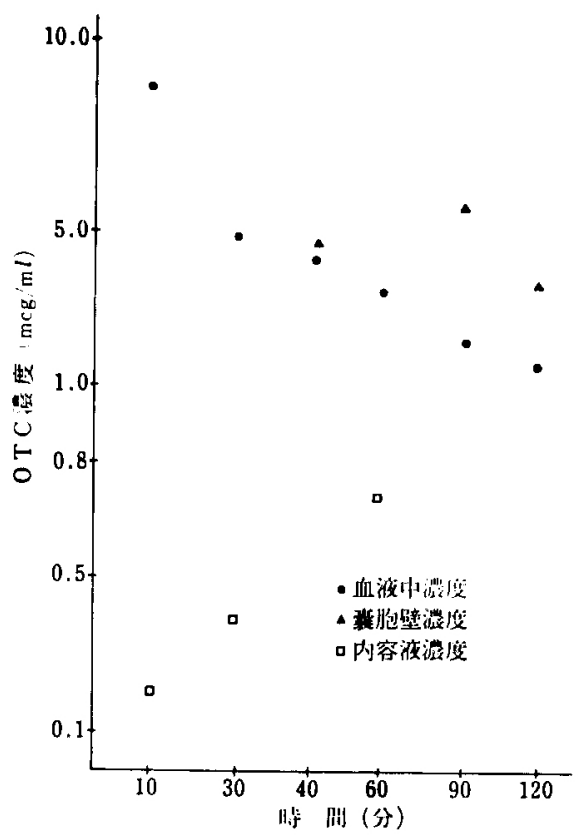

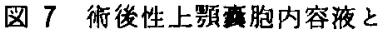
垔胞壁の OTC 灌度

から $20 \mathrm{~mm}$ の球状で，此較的溥い翼胞壁であった内内 層は主として重層扁平上皮層よりなり，部分的に綼毛上 皮が見られた症例むあった，基底部は比較的平坦で，線 維性結合組織層には炎症珄細胞浸潤はほとんど見られな かった（写真 6).

E 球状上罯事胞（图 9）

表 14 術後性上頻童胞内容液の OTC 灌度 $(\mathrm{mcg} / \mathrm{ml})$

\begin{tabular}{|c|c|c|c|c|c|c|c|c|c|c|}
\hline \multirow[b]{2}{*}{ 症例番号 } & \multirow[b]{2}{*}{ 静注前の抗菌力* } & \multicolumn{3}{|c|}{ 静注後 10 分 } & \multicolumn{3}{|c|}{ 静 注後 30 分 } & \multicolumn{3}{|c|}{ 静注後 60 分 } \\
\hline & & 内 容 液 & 血 & 液 & 内 容 液 & 血 & 液 & 内 容 液 & 血 & 液 \\
\hline 33 & 0.25 & \multirow{3}{*}{0.21} & \multirow{3}{*}{\multicolumn{2}{|c|}{ 8. 55}} & & \multirow{3}{*}{\multicolumn{2}{|c|}{ 4. 85}} & 0.68 & \multirow{3}{*}{\multicolumn{2}{|c|}{ 3. 45}} \\
\hline 34 & 0.10 & & & & & & & & & \\
\hline 35 & 0.16 & & & & 0.42 & & & & & \\
\hline
\end{tabular}

* OTC, 換算値

表 15 術後性上額軎胞壁の OTC 濃度 $(\mathrm{mcg} / \mathrm{ml})$

\begin{tabular}{|c|c|c|c|c|c|c|c|c|c|}
\hline \multirow[b]{2}{*}{ 症例番号 } & \multicolumn{3}{|c|}{ 静 注後 40 分 } & \multicolumn{3}{|c|}{ 静 注 後 90 分 } & \multicolumn{3}{|c|}{ 静注後 120 分 } \\
\hline & 輷 胞 壁 & 血 & 液 & 嚄 胞 壁 & 血 & 液 & 䞒 胞 壁 & 血 & 液 \\
\hline 33 & \multirow{3}{*}{ 4. 65} & \multirow{3}{*}{\multicolumn{2}{|c|}{ 4. 40}} & & \multirow{3}{*}{\multicolumn{2}{|c|}{ 2. 20}} & \multirow[t]{3}{*}{ 3. 55} & \multirow{3}{*}{\multicolumn{2}{|c|}{1.55}} \\
\hline 34 & & & & & & & & & \\
\hline 35 & & & & 5. 60 & & & & & \\
\hline
\end{tabular}




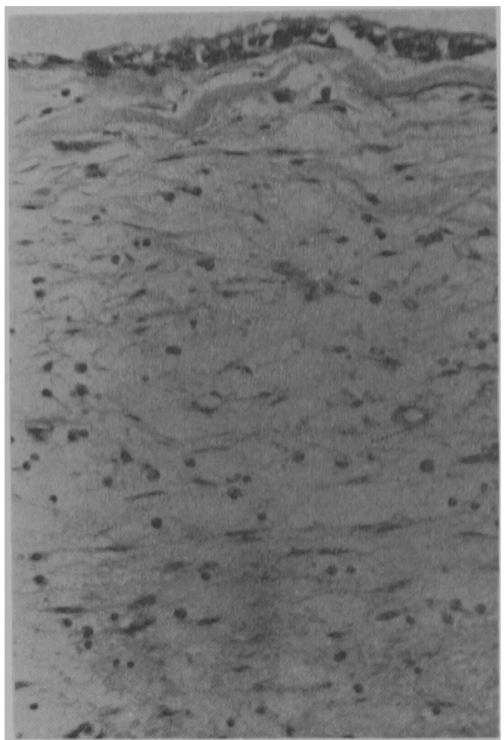

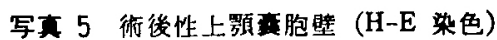
一層の緒毛上皮と路粗な線維性 結合組䋘層よりなる.

a 内容夜中の OTC 濃度：本症例は 1 例のみで，静 注 60 分後の内容夜瀑度は $0.88 \mathrm{mcg} / \mathrm{ml}$ で，その時の血 中漕度は $3.40 \mathrm{mcg} / \mathrm{ml}$ であった（表18）.

b 暴胞壁の OTC 濃度：静注 180 分後に摘出した童 胞壁浱度は $3.60 \mathrm{mcg} / \mathrm{ml}$ で，その時の血中濃度は 0.70 $\mathrm{mcg} / \mathrm{ml}$ であった (表19).

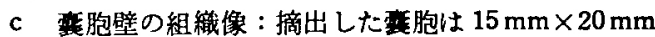

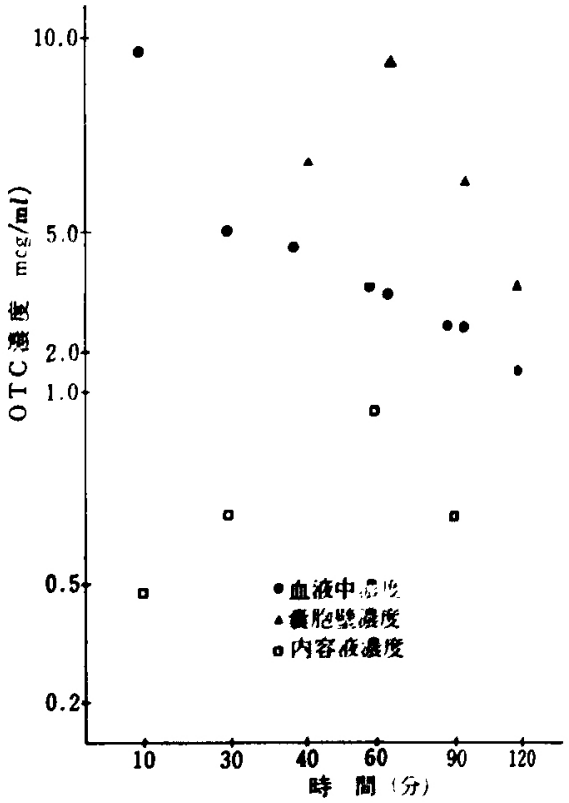

因 8 口蓋筑胞内容液と

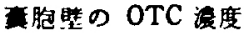

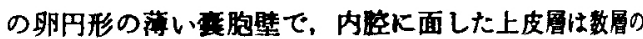
立方上皮よりなっており，これをとりまく外層は数相原 線䊒性結合組織よりなっていた。

F 震胞世エナメル上皮原（因10）

a 内容液中の OTC 港度: OTC 静注後に採取した

表 16 口蓋真胞内容液の OTC 浱度 $(\mathrm{mcg} / \mathrm{ml})$

\begin{tabular}{|c|c|c|c|c|c|c|c|c|c|c|c|c|c|}
\hline & & \multicolumn{3}{|c|}{ 静注御 10 分 } & \multicolumn{3}{|c|}{ 静注後 30 分 } & \multicolumn{3}{|c|}{ 静注啳 60 分 } & \multicolumn{3}{|c|}{ 静 注後 90 分 } \\
\hline 症例番号 & $\begin{array}{l}\text { 静注前の抗 } \\
\text { 囷先* }\end{array}$ & 内容 液 & 血 & 液 & 内容液 & 血 & 液 & 内容液 & 血 & 液 & 内容 液 & 血 & 海 \\
\hline 36 & 0.38 & & & & & & & & & & 0.58 & & 65 \\
\hline 37 & 0.42 & & & & 0.68 & & & & & & & & \\
\hline 38 & 0.33 & 0.48 & & & & & & & & & & & \\
\hline 39 & 0.23 & & & & & & & 0.85 & & 55 & & & \\
\hline
\end{tabular}

* OTC，換算值

表 17 蓋蕉胞壁の OTC 湿度 $(\mathrm{mcg} / \mathrm{ml})$

\begin{tabular}{|c|c|c|c|c|c|c|c|c|c|c|c|}
\hline & \multicolumn{3}{|c|}{ 静 注 後 40 分 } & \multicolumn{3}{|c|}{ 静 注 後 60 分 } & \multicolumn{3}{|c|}{ 㬹过後 90 分 } & \multicolumn{2}{|c|}{ 静注後 120 分 } \\
\hline 症例番号 & 晎 胞 壁 & 血 & & 糨 胞 壁 & 血 & 液 & 真胞壁 & 血 & 液 & 衰胞 壁 & 血 \\
\hline 36 & \multirow{4}{*}{5.85} & \multirow{4}{*}{\multicolumn{2}{|c|}{4.55}} & \multirow{4}{*}{ 9. 30} & \multirow{4}{*}{\multicolumn{2}{|c|}{ 3. 40}} & & \multirow{4}{*}{\multicolumn{2}{|c|}{2.60}} & 3. 65 & \multirow[t]{4}{*}{1.60} \\
\hline 37 & & & & & & & & & & & \\
\hline 38 & & & & & & & & & & & \\
\hline 39 & & & & & & & 6.30 & & & & \\
\hline
\end{tabular}




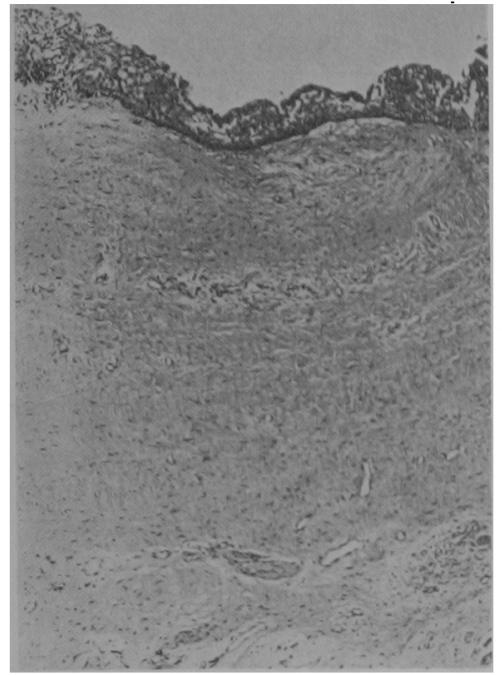

写真 6 鼻口蓋重胞壁 (H-E 染色) 重層屏平上皮ならびに一部 絾毛上皮が功られる。

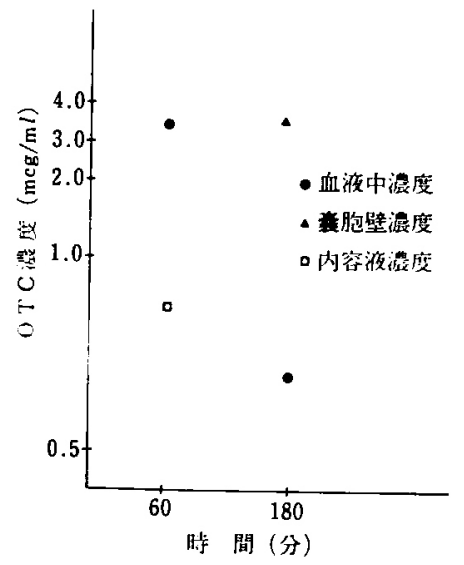

图 9 球状上顠巷胞内容液と 亯胞壁の OTC 濃度

表 18 球状上䫑毫胞内容液の OTC 濃度 (静注後60分) $(\mathrm{mcg} / \mathrm{m} l)$

\begin{tabular}{c|c|c|cr}
\hline 症例番号 & 静注前の抗菌力* & 内 容 液 & 血 & 液 \\
\hline 40 & 0.33 & 0.88 & 3.40 \\
\hline
\end{tabular}

* OTC, 換算値

内容液は 5 例で，その濃度は(表20)に示すよ5に，静注 10 分後では $0.50 \mathrm{mcg} / \mathrm{ml}, 30$ 分後は $0.78 \mathrm{mcg} / \mathrm{ml}, 60$ 分绻は $1.60 \mathrm{mcg} / \mathrm{ml}, 90$ 分後は $0.82 \mathrm{mcg} / \mathrm{ml}$ そして

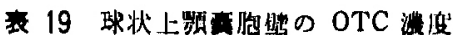

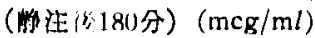

\begin{tabular}{|c|c|c|}
\hline 症例貫费 & 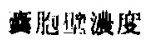 & 血 \\
\hline 40 & 3. 60 & 0.70 \\
\hline
\end{tabular}

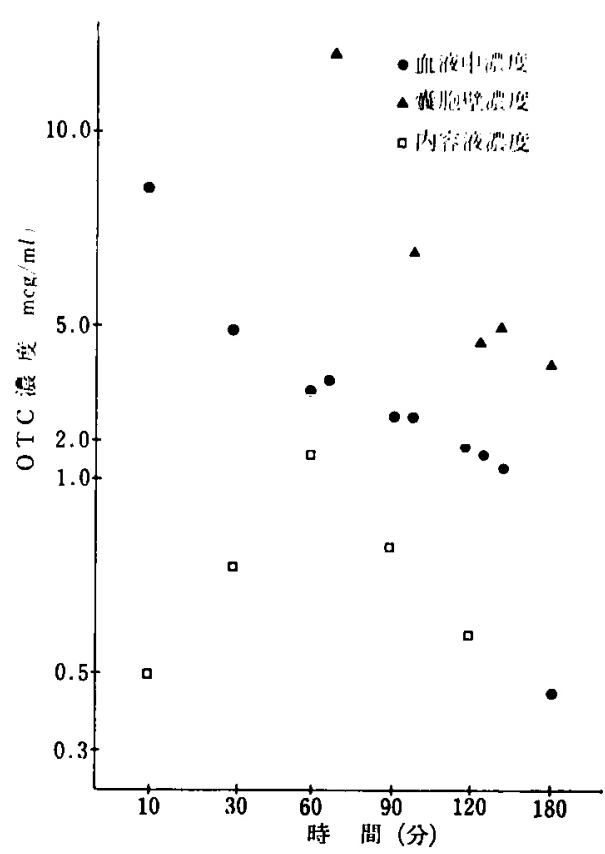

图 10 エナィル上皮腫（患胞性）内容液と 葆胞壁の OTC 湍度

120 分後は $0.60 \mathrm{mcg} / \mathrm{ml}$ で，その時の血中濃度は 8.60 $\mathrm{mcg} / \mathrm{ml}, 4.85 \mathrm{mcg} / \mathrm{ml}, 3.45 \mathrm{mcg} / \mathrm{ml}, 2.75 \mathrm{mcg} / \mathrm{ml}$, $1.80 \mathrm{mcg} / \mathrm{ml}$ であった.

b 葆胞壁の OTC 湢度 : OTC 静注後に摘出された

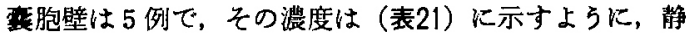
注60分後では $12.00 \mathrm{mcg} / \mathrm{ml}, 90$ 分後は $6.85 \mathrm{mcg} / \mathrm{ml}$, 120 分後は $4.50,4.80 \mathrm{mcg} / \mathrm{ml}$ そして 180 分後は 4.00 $\mathrm{mcg} / \mathrm{ml}$ て，その時の血中濃度は，3.65 $\mathrm{mcg} / \mathrm{ml} ， 2.60$ $\mathrm{mcg} / \mathrm{ml}, 1.55 \mathrm{mcg} / \mathrm{ml}, 1.35 \mathrm{mcg} / \mathrm{ml}, 0.45 \mathrm{mcg} / \mathrm{ml}$ で あった。

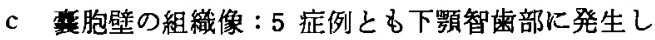
たもので，いずれも囦部下顎骨体より下顎枝部にわた る大きな単胞性のエナメル上皮腫で，堭胞壁は厚く，内 層は星状細胞と小莛胞の形成が見られ，腫湟上皮層には 間質が見られない，その下層は鬆粗な線維性結合組䅧よ りなり，腄瘍細胞の浸潤はほとんど見られない(写真 7 ).

\section{考察}

生体内に投与され，吸収されたTetracycline は主と して血流によって生体内を循環し，局所の病巣部に至る 


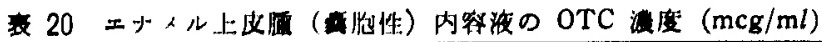

\begin{tabular}{|c|c|c|c|c|c|c|c|c|c|c|c|}
\hline \multirow[b]{2}{*}{ 定例番号 } & \multirow[b]{2}{*}{ 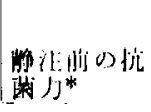 } & \multicolumn{2}{|c|}{ 消传 10 分 } & \multicolumn{2}{|c|}{$\|$ 证: 30 分 } & \multicolumn{2}{|c|}{ 栺注啳 60 分 } & \multicolumn{2}{|c|}{ 融良: 媵 90 分 } & \multicolumn{2}{|c|}{ 清 120 分 } \\
\hline & & 内容液 & 血 液 & 内行滩 & 血 液 & 内积淮 & 血 放 & 内容淮 & 血 淮 & 内容液 & 血海 \\
\hline 41 & 0.44 & & | & 0.78 & 4. 85 & & & & & & \\
\hline 42 & 0.48 & & & & & & & & & 0.60 & 1.80 \\
\hline 43 & 0.32 & 0.50 & 8. 60 & & & & & & & & \\
\hline 44 & 0.53 & & & & & 1.60 & 3. 45 & & & & \\
\hline 45 & 0.43 & & & & & & & 0.82 & 2.75 & & \\
\hline
\end{tabular}

* OTC, 換算候

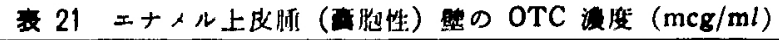

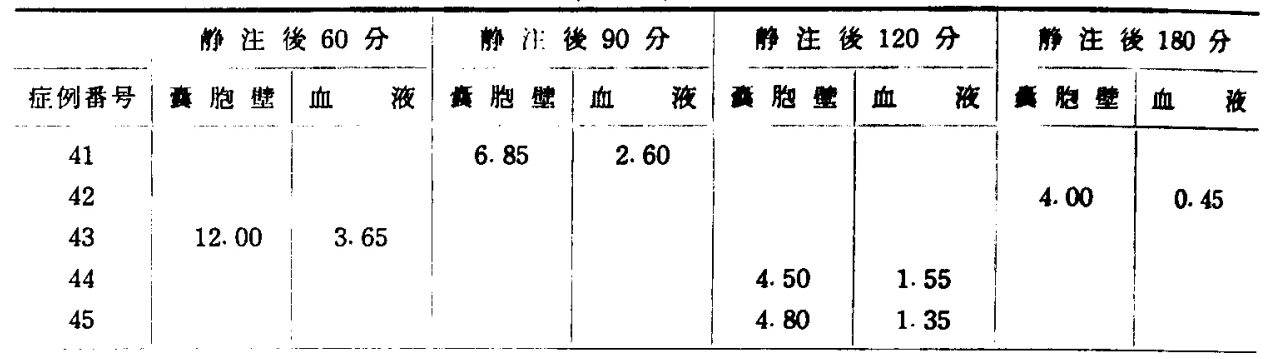

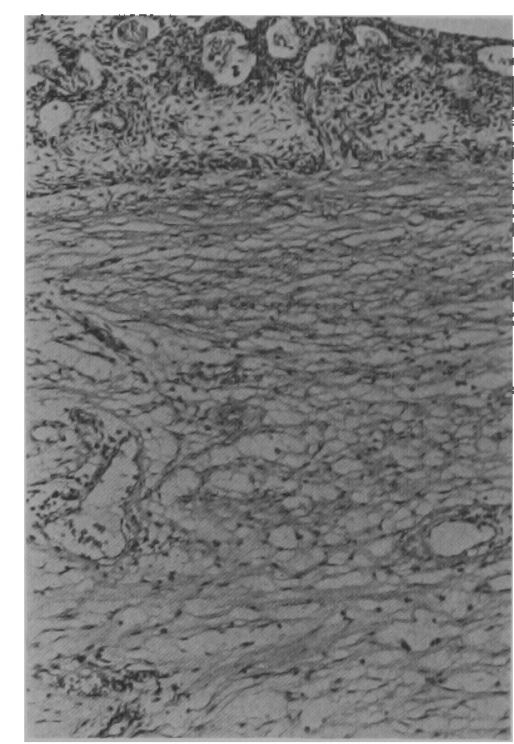

写真 7 亯胞性エナメル上皮茞 (H-E 染色) 内層は星状稩胞と小高胞の形成がみ られ，下層は箖粗な線維性結合組織 よりなる。

か，終局的には, Kelly $5(1960)^{18)}$, Kelly $5(1961)^{10)}$ のアイソトープによる実験で報告しているように，90\% は尿管などの排泄器に集まり, 残りの一部は骨格系に沈 着するといわれている。また今日まで Tetracycline の 体内分布，ことに組織内および病巣内への移行に関する
実検的研究数多〈報告されている，しかし，預骨内て

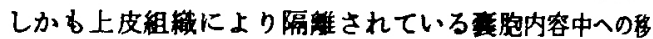
行に開する矿究報告は全くみられず，また茥胞内容液と

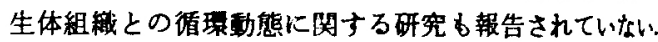
Tetracycline は生体内の金属イオン特飞 Ca イオンと 結合し20)，胎盤を通過したり，母乳中に移行することが 知られている21)。臨床上用いられた抗生物質が青胞内容 液中に移行与る時間的，是的变化忙投与方法，投与量下 より多少異なるが体液循棵の生理に密接な関連生がある と考えられる，宮村ら（1950）17)の報告によると，OTC は化学的に安定しており，血中でる $\mathrm{pH}$ の位正なしに 室温で24時間は力価不变であるとされているため, 体依 循謤のトレーサーの1つとして考えることるできる. 抗

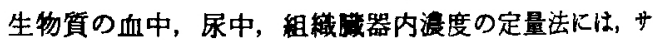
ルフォ剂の化学的定量法と異なり, 生物学的定量法か昿 く用いられている。著者は薄層カッブ法を用い, 使用菌 は OTCに感受性が強く，しかす芽胞を有しているため， 長期間にわたる実検でる米庫中て保存可能な B. subtilis PCI 219 株を用いた。地培地打よび被検液の $\mathrm{pH}$ 6.8にしたがこれは OTCが酸性培地において阻止月 がより明瞙になるためである.

著者が行っだ各症例の血中濃度の測定結果では, 重層 法を用いて測定した金子ら（1963） ${ }^{22)}$ の報告より低い做 であったが，これは測定方法や使用菌の差異によるすの と考えられる. しかし, 静注数分後に最高港度を示し, その後急速に減少する血中浿度のパターンは著者の結果 とほぼ一致していた。

静注前の垔胞内容液は B. subtilis PCI 219 株に対し 
て，OTC 灌度に換算して最低 $0.10 \mathrm{mcg} / \mathrm{ml}$ から最高 $0.53 \mathrm{mcg} / \mathrm{ml}$ の抗菌性を梕めたが,これは安室 $(1959)^{28)}$ の研究報告にみられるよ5に人羊水中にも娭定菌に対し て軽度の抗菌性をすつのと同様であるが，その本体につ いては究明されていない，しかし，静注後の黄胞内容液 中下移行した OTC 濃度は狰注前内容液の抗菌力上り。 はるかに高い湠度であった。このことは明らかに OTC が套胞内容液中への移行を示するのであり，京胞内容液 中の OTC の時間的消長は血中䈨度のパターンとほぽ致している.しかし，血中灌度は静注 5 分後で取高灌度

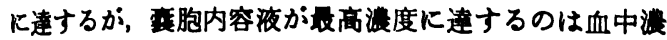
度のそれよりす約60分幄れている．しかる内容液の取高

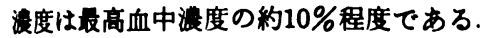

鳥居 $(1960)^{\circ)}$ に上る Tetracycline の娌物炎症栄へ

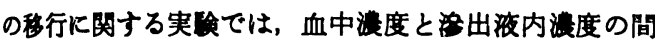
に怯，時間的推移に関して約 30分〜120 分のずれがあり， しかる出液内濩度は最高血中㵊度の約 $30 \%$ の值を示す

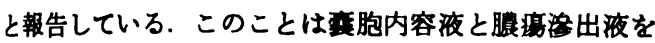
同一に論ずることはできないとしても，今回の烡胞内容 液と血中灌度との関係によく近似している。

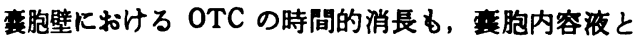
同様，血中䈨度のパターンとほぼ一致していたか，䨢胞 壁の OTC か樶高港度に達する時間は内容液と同様，血 中潵度か最高浱度に達する時間よりも約60分遈れていた また，訔胞壁の最高濃度は最高血中㳻度の約 $80 \%$ であっ た. 静注後 40分から 180 分までに摘出されたすべての蒉 胸壁港度は，その摘出時の血中港度よりるつわに高蕞度 であった。このことは今まで行われた病巣組織内䈨度と 血中淩度の関係とよく似ている.

萣胞壁の形態学的な差異による OTC 移行の差につい ては, 歯根毫胞例の内容液, 霆胞壁浱度ともに多少のば らつきが見られるが，大きな浱度変化は認めなかった。 しかし，訹後性上䫑旁胞例においては内容夜，莫胞壁と るにやや低い值を示し，エナメル上皮腫例においてはや 中高い值を示した．このことは同じ蓄胞形成疾患であっ ても，その発生および発育形態などが異なるためではな いかと考えられる.

以上のように，哄胞内容液中に移行した OTC 浱度は， 通常の臨床的投与量ではグラム陽性菌群の球菌に対する MIC よりは高い浱度であるが，その有効浱度の持続時 间は血中漫度に比べると短い。したかっって蓄胞内容液中 の取小発育阻止浱度を長時間にわたって保持するために 恃，投与方法，投与量を十分に配虑する必要があると考 えられる。

\section{結論}

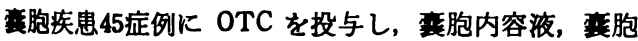
壁への移行を薄層カッブ法を用いた生物学的定量法によ って测定し，次のような結論を得た。
1. 英胞内容液は B. subtilis PCI 219 侏に対して器

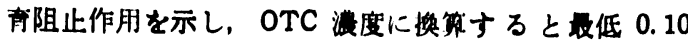
$\mathrm{mcg} / \mathrm{ml}$ から最高 $0.53 \mathrm{mcg} / \mathrm{ml}$ の抗菌力を恕めた。

2. 血中漠度は狰注 5 分後で最高港度快均 $12.40 \mathrm{mcg} /$ $\mathrm{ml}$ に迲し，その後色速に減少し，60分後には性了3.65 $\mathrm{mcg} / \mathrm{ml}$ であった.

3. 筫胞内容液へ明らかに OTCの移行が琶められ,

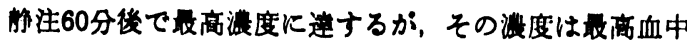
漠度の約10\%であった。

4. 暻胞内容液中に移行した OTC は静注 120 分後で 大部分が消失した。

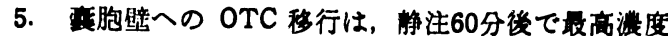

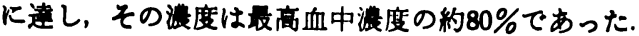

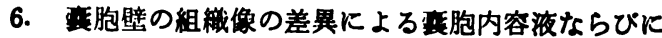
英胞壁 OTC 港度は，エナメル上皮腫例においてはやや 高く，術後性上頴变胞例においてはやや低い值を示した か，その他の葚胞例においては認むべき差は現われなか った.

䅻を終わるにあたり、こ校成を媔いた高須淳教授な らびと岡野博郎教授に深謝し，また終始こ指算を頂いた 飯田 武助教授と種々のこ援助を媔いた教室員各位に深 甚の謝意を申しのへます。

この論文の要旨は，第17回日本口胫外科学会総会（昭 和47年10月 7 日，福岡）お上び第 221 回大阪齿科学会例 会（昭和49年10月12日，大阪）飞扰いて発表した。

文献

1) Bhaskar, N. : Periapical lesions, Types, Incidence, and Clinical Features. Oral Surg 21 6561966.

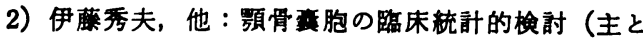

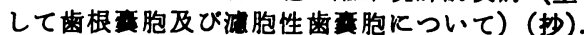
口科誌 $18: 241.1969$.

3）斉藤幸一，他 過去 5 年間飞おける口腔領域㥶胞 性疾患の臨床統計的钼察. 日口外誌 $19: 3531973$

4）大久保 潈，他：テトラサイクリン（フクロマイ シン) の腈器内分布並びに胆计内排泄飞ついて。 J Antibiot $7: 2871954$.

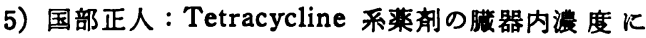
ついて. 岩手医誌 $8: 4461957$.

6）鳥居敏雄：化学療法と内科臨床 I. 抗生郕の吸収, 排泄，体内分布飞関与る研究。日内会誌 $49: 908$ 1960.

7）嶋田甚五郎：抗生刜の体内動態炕関する研宛。 Tetracycline の発虽光能の応用. 孶医誌 $87: 12$ 1972.

8）成川誠義：抗生物質の口腔組機内湠度炕関する実 的研究. 齿科医学 $21: 7951958$.

9）内藤 博，他：口腔外科領域における Spiramycin の臨床的および実臨的研究. 歯界展望 22： 7201963.

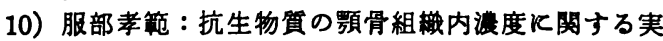
験的研究，第 2 編 諸種抗生物質飞ついて。只科 
誌 $14: 2901965$.

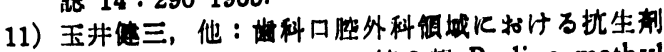

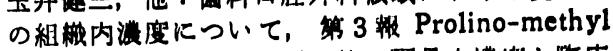

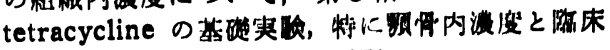
好果. 日日外战 $17: 392 ， 1971$.

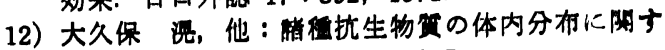
万研究. 日内会䏯 $43: 5181955$.

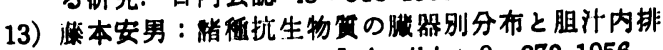

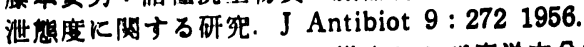

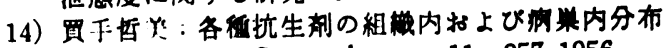

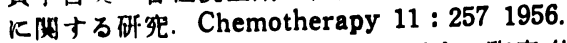

15）岩沢武度，他：Doxycycline に成する臨床的な らびそ実㻌的研宪. Chemotherapy $17: 3991963$.

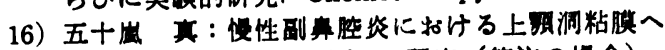
の抗生物筫移行度に阅士る研究（筇注の或合）。 日耳算 $61: 14401958$.

17）宮村定男，他：Terramycin の Cup 椧定につい $\tau$. J Antibiot $4: 4701950$.

18) Kelly, R. G., et al. : Metabolism of tetracycline in the rat and the dog. J Pharmacol Exp er Therap $130: 1441960$.

19) Kelly, R.G., et al. : The metabolism and tissue distribution of radioisotopically labeled demethylchlortetracycline. J Pharmacol Exper Therap $134: 3201961$.

20) Weinberg, F.D. : The mutual effects of antimicrobial compounds and metallic cations. $\mathrm{Ba}$ ct Rev $21: 461957$.

21) Johnson, H. R. : The tetracyclines : $\mathbf{A}$ review of the literature-1948 through 1963 . J $0 \mathrm{ral}$ Therap Pharmacol 1: 1901964.

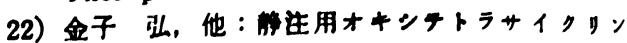


$16: 3091963$.

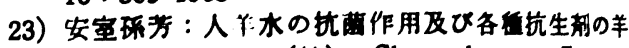
水移行Kついて (抄). Chemotherapy $7: 223$ 1959. 